\title{
PSICOPEDAGOGIA E A TEORIA MODULAR DA MENTE
}

\author{
Psychopedagogic and the Modular Theory of Mind
}

Mariana Alves Said ${ }^{1}$

\author{
Veiga, E.C. \& Garcia, E.G. (2006). Psicopedagogia e a teoria modular da mente. São José dos \\ Campos: Pulso.
}

Os autores apresentam em seu livro teorias que sustentam a nova concepção que eles propõem para a psicopedagogia, denominada PSICOPEDAGOGIA MODULAR. Sua leitura convida profissionais que trabalham com aprendizagem e que estão preocupados com o futuro desenvolvimento deste campo do conhecimento a repensarem sua prática sob este novo enfoque teórico. Este livro apresenta a Modularidade da Mente, discute a Modularidade e o Construtivismo e propõe a Psicopedagogia Modular.

Defendem a idéia de que o novo perfil do psicopedagogo na perspectiva modular é potencializar ao máximo o sistema mental com o objetivo de auxiliar o êxito não só na escola, mas também na vida fora dela, no mundo pessoal e profissional do sujeito. As suposições teóricas não limitam a influência na investigação que se poderia qualificar como básica e sim que o conhecimento teórico que se põe em prática por meio de diversas tecnologias e intervenções na realidade pessoal e sociocultural chegam a determinar o tipo de potencialidades humanas que se desenvolvem e o que é sancionado culturalmente. Nesse sentido, as suposições sobre a natureza humana influenciam no que de fato a pessoa chega a ser em um meio sociocultural determinado, isto é especialmente relevante para a Psicopedagogia.

As teorias e modelos psicológicos que durante o século XX fundamentaram a teoria e prática psicopedagógica, tanto em educação normal como educação especial, têm conceitualizado a mente como uma capacidade de domínio geral. O suposto psicológico básico em todas as classificações é um funcionamento mental geral ou uma mente de domínio geral, frente a uma concepção de tipo modular ou de domínio específico. Este suposto básico atualmente está sendo radicalmente questionado. Nesse livro, os autores propõem algumas chaves para reelaborar um marco teórico mais condizente com os novos estudos e uma prática profissional ainda mais eficaz.

Mariana Alves Said. Estudante do curso de Psicologia da PUCPR, 6º período. 
O livro está estruturado em três partes. A Parte I contempla 5 capítulos. O Capítulo 1 nos fala das novas tecnologias que põem à prova teorias e modelos modulares da mente, apresentando dados experimentais que apóiam uma perspectiva modular. No Capítulo 2, encontra-se a Teoria Modular passando pela concepção fodoriana até as investigações da Neuropsicologia. No Capítulo 3, a funcionalidade da modularidade a partir de mentes estruturadas em módulos ou sistemas programados para as aprendizagens. O modelo de Teoria Modular da Mente fundamentada na neuropsicologia encontra-se no Capítulo 4, com a apresentação da Teoria das Inteligências Múltiplas, que propõe uma visão alternativa da mente, reconhecendo que as pessoas têm diferentes potenciais cognitivos, baseados em um potencial biológico, o qual é expresso como resultado da integração dos fatores genéticos e ambientais. O Capítulo 5 apresenta a Teoria Triárquica que propõe um modelo tridimensional para compreender e desenvolver a inteligência.

A Parte II dedica-se ao Capítulo 6, que apresenta um paralelo entre a modularidade e o construtivismo e a Parte III contém dois capítulos, o Capítulo 7 que se ocupa de uma nova proposta para a Psicopedagogia com base na Teoria Modular da Mente e o Capítulo 8 que apresenta a Aplicação de um Programa de Intervenção Cognitiva com base na Teoria Modular da Mente (PIC).

Os autores destacam a necessidade de se iniciar um movimento nas escolas em busca do desenvolvimento de todas as inteligências humanas para maximizar a probabilidade de sucesso do indivíduo no mundo real, assim como repensar a função do psicopedagogo e sua práxis. Afirmam que o psicopedagogo neste novo milênio será um profissional que identificará o perfil cognitivo do sujeito, passando a potencializar todas as habilidades, deixando de lado a proposta centrada nas dificuldades de aprendizagem, pois estas estão embasadas na visão tradicional de inteligência acadêmica. A práxis do psicopedagogo na perspectiva modular é potencializar ao máximo o sistema mental do sujeito com o objetivo de auxiliar a obtenção do sucesso não só na escola, situação circunstancial, mas na vida fora da escola, no mundo pessoal e profissional.

Recebido em: 10/08/2007

Received in: 08/10/2007

Aprovado em: 06/09/2007

Approved in: 09/06/2007 